\title{
Peran Keluarga dalam Penerapan Protokol Kesehatan Selama Pandemi Covid-19
}

\author{
Irma Darmawati.,M.Kep.,Ns.Sp.Kep.Kom
}

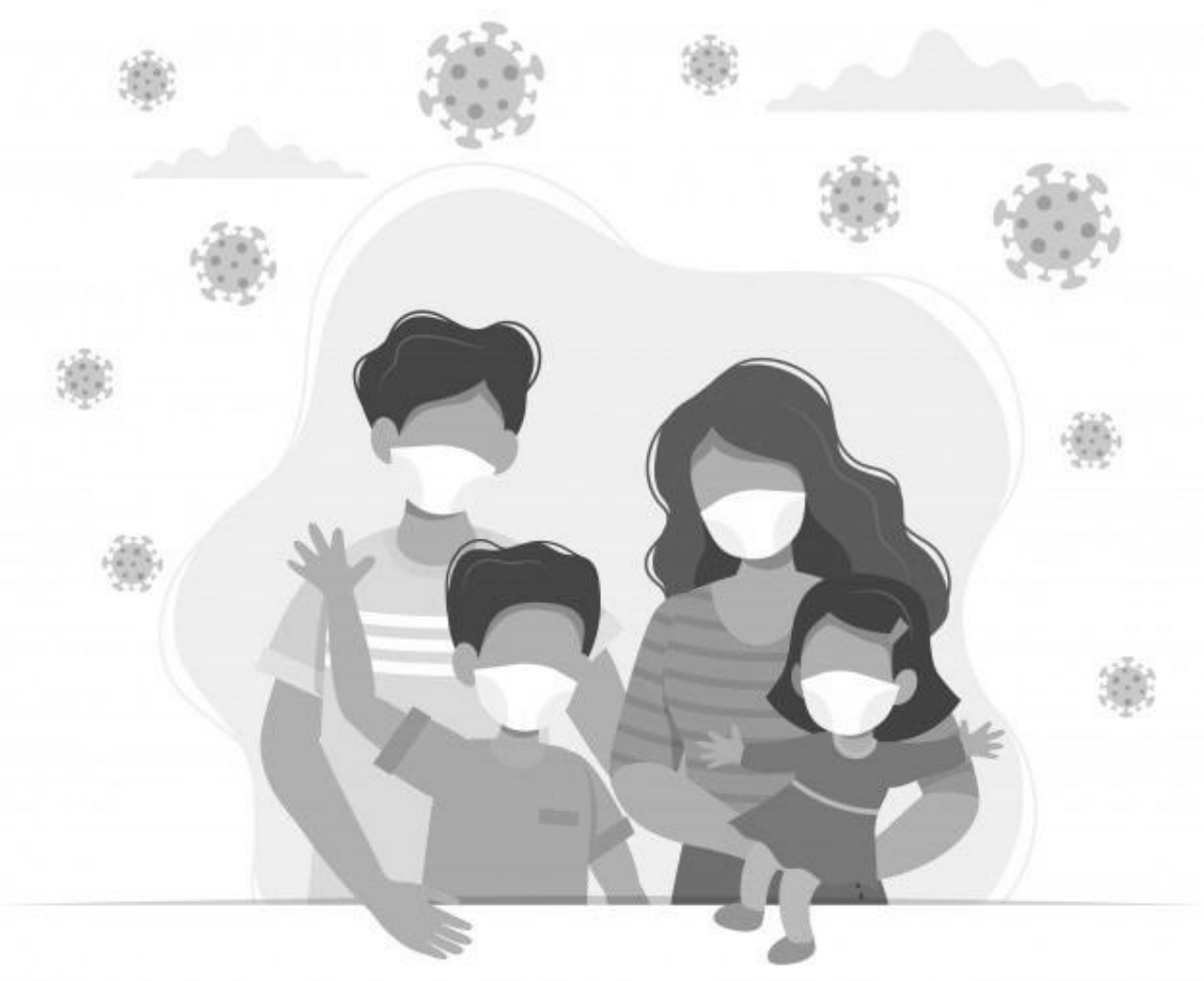

Kajian ini membahas peranan setiap anggota keluarga sebagai sistem pendukung bagi anggota keluarga lainnya. Penatalaksanaan peran keluarga memegang peranan besar dalam upaya pencegahan dan pengendalian Covid-19 di Indonesia. Bab ini menyajikan pengetahuan dasar penting mengenai peran keluarga selama masa pandemi Covid-19. 
Pandemi Coronavirus Disease 2019 (COVID-19), disebabkan oleh Severe Acute Respiratory Syndrome-related Coronavirus 2 (SARS-CoV-2) pada akhir Desember 2019 di Wuhan, China. Sampai dengan akhir bulan Februari 2021, dilaporkan terdapat sejumlah 111.762 .965 kasus dan mengakibatkan lebih dari 2.479.678 kematian di seluruh dunia (WHO, 2021). Penyebaran Covid-19 terkonfirmasi dapat menular dari manusia ke manusia melalui percikan droplet, dan berkembang kajian selanjutnya bahwa juga covid-19 dapat ditularkan secara airborne melalui udara (Borak, 2020; WHO, 2020a)

Pandemi Covid-19 menimbulkan berbagai dampak pada seluruh bangsa termasuk komponen keluarga di dalamnya. Selama pandemi, pengalaman setiap orang adalah unik, tetapi kita semua menghadapi stres dan kekecewaan baru karena berbagai alasan (Watamura \& Koppels, 2020). Bagi sejumlah keluarga, ini bisa berarti membuat perubahan besar dalam rutinitas sehari-hari karena kesulitan keuangan. Untuk keluarga lain, itu bisa berarti kecemasan yang meningkat pada ibu terkait kesehatan anggota keluarga, ketakutan dalam pengambilan keputusan kesehatan, sampai ketegangan dalam aktifitas sekolah daring (Malkawi, Almhdawi, Jaber, \& Alqatarneh, 2020). Perubahan dalam pekerjaan, sekolah, dan kehidupan secara umum telah memaksa para ibu khususnya untuk menanggung beban dan beradaptasi dengan tugas tambahan dan peningkatan tingkat stres yang disebabkan oleh pandemi Covid-19 yang tidak terduga sebelumnya (Kalil, Mayer, \& Shah, 2020).

Rekomendasi upaya pencegahan Covid-19 di dunia tertulis dalam WHO's interim guidance on infection prevention and control (IPC) strategies during Covid-19 (WHO, 2020a), menyebutkan 3 prinsip dan rekomendasi standar sebagai upaya pencegahan penyebaran infeksi. Rekomendasi tersebut kemudian diatur dalam KMK Nomor HK.01.07/Menkes/413/2020 tentang pedoman pencegahan dan pengendalian Covid-19 di Indonesia (Kemenkes RI, 2020). Keputusan Menteri Kesehatan ini merupakan jabaran turunan dari UU No. 4 Tahun 1984 tentang wabah penyakit menular, PP No. 40 Tahun 1991 tentang penanggulangan wabah penyakit menular (Presiden Republik Indonesia, 2013), serta Peraturan menteri Kesehatan No. 1501/Menkes/Per/X/2010 tentang jenis penyakit menular tertentu yang dapat menimbulkan wabah dan upaya penanggulangannya (Kementrian Kesehatan Republik Indonesia, 2011).

KMK Nomor HK.01.07/Menkes/413/2020 merupakan produk hukum Keputusan Menteri Kesehatan yang mengatur pedoman pencegahan dan pengendalian Covid-19 untuk menjadi acuan bagi Pemerintah Pusat, Pemerintah Daerah Provinsi, Pemerintah Daerah Kabupaten/Kota, fasilitas pelayanan kesehatan, tenaga kesehatan, serta seluruh pihak terkait dalam melakukan upaya pencegahan dan pengendalian Covid-19. Pedoman ini menjelaskan penularan Covid-19 terjadi melalui droplet yang mengandung virus SARS-CoV-2 yang masuk ke dalam tubuh melalui hidung, mulut dan mata, untuk itu pencegahan penularan 
Covid-19 pada individu dilakukan dengan beberapa tindakan, seperti: (a) Membersihkan tangan secara teratur dengan cuci tangan pakai sabun dan air mengalir selama 40-60 detik atau menggunakan cairan antiseptik berbasis alkohol (bandsanitizer) minimal 20-30 detik, hindari menyentuh mata, hidung dan mulut dengan tangan yang tidak bersih. (b) Menggunakan alat pelindung diri berupa masker yang menutupi hidung dan mulut jika harus keluar rumah atau berinteraksi dengan orang lain yang tidak diketahui status kesehatannya (yang mungkin dapat menularkan Covid-19). (c) Menjaga jarak minimal 1 meter (pembatasan fisik) dengan orang lain untuk menghindari terkena droplet dari orang yang batuk atau bersin. Jika tidak memungkin melakukan jaga jarak maka dapat dilakukan dengan berbagai rekayasa administrasi dan teknis lainnya. (d) Membatasi diri terhadap interaksi / kontak dengan orang lain yang tidak diketahui status kesehatannya. (e) Saat tiba di rumah setelah bepergian, segera mandi dan berganti pakaian sebelum kontak dengan anggota keluarga di rumah. (f) Meningkatkan daya tahan tubuh dengan menerapkan pola hidup bersih dan sehat (PHBS) seperti konsumsi gizi seimbang, aktivitas fisik minimal 30 menit sehari, istirahat yang cukup termasuk pemanfaatan kesehatan tradisional (Kemenkes RI, 2020).

Penerapan protokol kesehatan tersebut tidak dapat dipatuhi secara langsung oleh masyarakat. Hal ini membutuhkan peran keluarga utamanya orang tua untuk mengambil keputusan kesehatan yang terbaik bagi keluarganya. Perilaku sehat (health behavior) awalnya dibentuk di keluarga melalui pembentukan nilai kesehatan (health values), kebiasaan sehat (health habit) dan persepsi terhadap risiko kesehatan (bealth risk perception) (Stanhope, Faan, Lancaster, \& Faan, 2019). Pendapat lain dikemukakan oleh Green (1980) dalam Notoatmodjo (2012) yang menyatakan bahwa perilaku kesehatan ini dipengaruhi tiga faktor utama, yaitu faktor predisposisi (predisposing factors) meliputi tingkat pengetahuan, sikap, norma, nilai dan faktor demografi, selanjutnya faktor pemungkin (enabling factors) seperti ketersediaan fasilitas untuk melakukan suatu perilaku, serta faktor penguat (reinforcing factor) seperti perilaku orang lain atau tenaga kesehatan. Kedua pendapat tersebut saling mendukung, jika kita menyimpulkan bahwa nilai kesehatan, kebiasaan sehat, dan persepsi terhadap risiko kesehatan yang dimaksud Stanhope dan Lancaster (2012) dapat dibentuk melalui faktor-faktor yang disebutkan Green (1980, dalam Notoatmodjo, 2012). Nilai kesehatan, kebiasaan dan persepsi seseorang dapat terbentuk dari luasnya wawasan dan pengetahuan seseorang sehingga memiliki nilai kesehatan yang baik, nilai-nilai masyarakat yang sehat, ketersediaan fasilitas kesehatan, dan juga contoh perilaku yang baik dari keluarga dan masyarakat di sekeliling individu tersebut.

Keluarga merupakan orang orang yang disatukan dalam ikatan perkawinan, darah dan ikatan adopsi. Para anggotanya hidup bersama-sama dalam satu rumah tangga, saling berinteraksi dan berkomunikasai satu dengan yang lain dalam peranperan sosial keluarga (Friedman, Bowden, \& Jones, 2010). Dalam mencapai tujuan 
hidup berkeluarga ini, terdapat beberapa fungsi keluarga yang harus dipenuhi, diantaranya:

- Fungsi Afektif

Fungsi keluarga yang utama untuk mengajarkan segala sesuatu untuk mempersiapkan anggota keluarga berhubungan dengan orang lain. Fungsi ini dibutuhkan untuk perkembangan individu dan psikososial anggota keluarga.

- Fungsi Sosialisasi dan tempat bersosialisasi

Keluarga sebagai tempat mengembangkan dan tempat melatih anak untuk berkehidupan sosial sebelum meningkalkan rumah untuk berhubungan dengan orang lain di luar rumah.

- Fungsi reproduksi

Fungsi keluarga untuk mempertahankan generasu dan menjaga kelangsungan keluarga.

- Fungsi ekonomi

Fungsi keluarga untuk memenuhi kebutuhan keluarga secara ekonomi dan tempat untuk mengembangkan kemampuan individu meningkatkan penghasilan untuk memenuhi kebutuhan keluarga.

- Fungsi perawatan kesehatan

Fungsi keluarga untuk mempertahankan keadaan kesehatan anggota keluarga agar tetap memiliki produktivitas tinggi. Fungsi ini dikembangkan menjadi tugas keluarga di bidang kesehatan.

Friedman, Bowden, \& Jones (2010) mengungkapkan bahwa keluarga memiliki lima tugas keluarga di bidang kesehatan itu diantaranya:

- Mengenal masalah kesehatan keluarga. artinya, keluarga harus mengetahui apa itu penyakit, apa penyebabnya, apa gejalanya, bagaimana merawatnya, dan apa komplikasinya.

- Memutuskan tindakan kesehatan yang tepat bagi keluarga. artinya, keluarga dapat mengambil tindakan untuk mengatasi masalah kesehatan yang dihadapi. Misalnya, membawa anggota keluarga yang sakit berobat ke fasilitas kesehatan, seperti dokter, puskesmas, ataupun rumah sakit.

- Merawat keluarga yang mengalami gangguan kesehatan. Artinya, keluarga diharapkan mampu merawat dengan benar anggota keluarganya yang sakit agar segera sehat seperti sebelumnya.

- Memodifikasi lingkungan keluarga untuk menjamin kesehatn keluarga. misalnya, dengan memelihara lingkungan tempat tinggalnya agar tidak menimbulkan penyakit.

- Memanfaatkan fasilitas pelayanan kesehatan di sekitarnya bagi keluarga. artinya, keluarga akan membawa anggota keluargnya yang sakit ke fasilitas kesehatan terdekat atau fasilitas kesehatan yang disukai. 
Tugas kesehatan keluarga ini menjadi dasar bagi keluarga dan tenaga kesehatan untuk menilai kesiapan keluarga dalam menghadapi situasi sakit atau resiko penyakit seperti Covid-19 salah satunya. Dalam praktiknya keluarga harus mampu mengenal masalah kesehatan yang ada pada masa pandemi ini. Keluarga harus memahami apa itu penyakit Covid-19, apa penyebabnya, apa gejalanya, bagaimana merawatnya, dan apa komplikasinya yang mungkin terjadi pada setiap anggota keluarga. Anggota keluarga memiliki keunikan dan ke khas an masingmasing dalam menghadapi resiko penyakit. Anggota keluarga lansia contohnya memiliki resiko yang lebih tinggi terkena penyakit ini dikarenakan imunitas tubuh yang lebih rendah daripada anggota keluarga lainnya yang masih berusia remaja dan dewasa. Jika seluruh anggota keluarga mampu mengidentifikasi faktor resiko pada setiap orang, maka keluarga dapat mengambil upaya pencegahan lebih dini untuk menghindari Covid-19.

Tugas kesehatan yang kedua adalah memutuskan tindakan kesehatan yang tepat bagi keluarga. Keluarga akan mengambil tindakan untuk mengatasi masalah kesehatan yang dihadapi. Selama masa pandemi ini jika keluarga sudah mampu mengenal masalah kesehatan yang diakibatkan virus SARS-CoV-2, maka keluarga akan memutuskan upaya pencegahan salah satunya untuk memastikan setiap anggota keluarga melakukan protokol kesehatan secara benar. Protokol kesehatan yang harus disepakati dan difasilitasi dalam keluarga ini diantaranya :

- Membersihkan tangan secara teratur dengan cuci tangan pakai sabun dan air mengalir selama 40-60 detik atau menggunakan cairan antiseptik berbasis alkohol (handsanitizer) minimal 20-30 detik. Dalam penerapan poin ini keluarga berperan untuk memfasilitasi tersedianya cukup air, memastikan keran di depan rumah menyala, menyiapkan sabun cair, atau juga menyiapkan hand sanitizer di area sebelum masuk rumah dan juga di dalam rumah yang mudah untuk dijangkau seluruh anggota keluarga.

- Menggunakan alat pelindung diri berupa masker yang menutupi hidung dan mulut. Dalam penerapan poin ini keluarga berperan untuk memfasilitasi tersedianya cukup masker untuk seluruh anggota keluarga. Teknis penggunaan masker ini dapat disesuaikan dengan kebutuhan dan kesanggupan setiap keluarga. Masker yang dapat digunakan untuk pencegahan covid ini bisa menggunakan masker bedah, masker N95, masker daily use non medis, masker kain. Berdasarkan efektivitasnya, masker medis memang diketahui memiliki tingkat paling tinggi. Masker jenis N95 misalnya, didesain untuk memblokir 95\% partikel yang sangat kecil. Begitu juga dengan masker bedah, sehingga masker medis sangat efektif untuk mencegah paparan virus. Namun dalam penerapan nya pada keluarga ini dapat disesuaikan dengan aktifitas dan resiko keterpaparan setiap anggota keluarga. Beberapa ketentuan penggunaan masker yang harus dipatuhi seluruh anggota keluarga diantaranya harus 
menutup rapat bagian hidung, pipi, dan dagu. Bentuknya dapat berupa pipih-terlipat atau duckbill. Bila tidak tertutup rapi, masker dapat menyebabkan kebocoran udara yang masuk maupun keluar tanpa tersaring.

- Menjaga jarak minimal 1 meter (pembatasan fisik) dengan orang lain untuk menghindari terkena droplet dari orang yang batuk atau bersin. Setiap anggota keluarga harus faham akan prinsip penyebaran virus ini. Keluarga memegang peranan tinggi untuk mengedukasi setiap anggota keluarga untuk menjaga jarak minimal 1 meter. Dua penelitian dari Wuhan dan Hongkong melaporkan adanya penurunan kasus transmisi akibat covid setelah penerapan kebijakan physical distancing. Penerapan physical distancing pada 149 negara di dunia menunjukan adanya penurunan insidensi Covid-19 sebanyak 13\% (IRR 0.87, 95\% confidence interval 0.85 ke 0.89; $\mathrm{n}=149$ negara) (Islam et al., 2020). Beberapa anjuran terkait pembatasan fisik tersebut diantaranya : Dilarang berdekatan atau kontak fisik dengan orang mengatur jaga jarak minimal 1 meter, tidak bersalaman, tidak berpelukan, berciuman, hindari penggunaan transportasi publik, dilarang berkumpul massal di kerumunan dan fasilitas umum, membatasi jumlah pengunjung dan waktu kunjungan.

- Membatasi diri terhadap interaksi / kontak dengan orang lain yang tidak diketahui status kesehatannya. Anjuran ini dikenal pula dengan slogan Stay at home. Sebisa mungkin tidak bepergian dan menghindarkan diri untuk kontak dengan orang lain yang tidak jelas riwayat dna kondisi kesehatannya secara pasti oleh seluruh anggota keluarga. Pandemi ini menempatkan ibu dalam situasi yang sangat sulit. Ibu bertindak sebagai pengasuh utama bagi seluruh anggota keluarga, ibu menanggung beban berat membantu seluruh anggota keluarga untuk tetap melaksanakan peran dan tugas sosialnya walaupun berada di rumah saja (Spinelli, Lionetti, Pastore, \& Fasolo, 2020). Ibu mendampingi anak-anak membiasakan diri dengan pembelajaran online, di saat yang sama mereka pun bekerja dari rumah. Pada ibu bekerja, hal ini mengganggu jadwal kerja mereka, dan ibu merasa perlu bekerja lebih lama, baik pekerjaan rumah maupun pekerjaan kantornya, sehingga semakin membebani keseimbangan kehidupan kerja mereka (Kalil et al., 2020). Sikap pengertian dan saling membantu dari anggota keluarga yang lain dibutuhkan dalam situasi ini agar kualitas hidup ibu tetap optimal, dan fungsi keluarga berjalan sebagaimana mestinya.

- Saat tiba di rumah setelah bepergian, segera mandi dan berganti pakaian sebelum kontak dengan anggota keluarga di rumah. Keluarga berperan untuk saling mengingatkan kebersihan dari setiap anggota keluarga jika 
telah bepergian. Anggota keluarga yang telah bepergian diharuskan cuci tangan sebelum masuk rumah, segera mandi dan berganti pakaian sebelum kontak dengan anggota keluarga lainnya di rumah. Hal ini menjadi sebuah rutinitas yang akan melelahkan, sehingga diharapkan semua anggota keluarga bersepakat dan saling mendukung dalam menjalankan protokol kesehatan.

- Meningkatkan daya tahan tubuh dengan menerapkan pola hidup bersih dan sehat (PHBS) seperti konsumsi gizi seimbang, aktivitas fisik minimal 30 menit sehari, istirahat yang cukup termasuk pemanfaatan kesehatan tradisional. Pada protokol ini keluarga diharuskan untuk saling menjaga kekebalan tubuh satu sama lain dengan memfasilitasi konsumsi makanan seimbang, menjaga kebersihan rumah, berjemur jika memungkinkan, saling mengingatkan untuk beristirahat yang cukup, dan bersama sama melaksanakan aktifitas fisik minimal 30 hari walaupun tidak diluar rumah. Menurut WHO, aktivitas fisik di rumah perlu tetap dilakukan, baik berupa olahraga maupun gerakan biasa yang melemaskan otot (Hart, Turnbull, Oppenheim, \& Courtright, 2020). Latihan fisik secara teratur bermanfaat bagi kebugaran tubuh dan pikiran. Aktivitas fisik yang mengarah pada olahraga rutin juga berguna menurunkan risiko stroke, tekanan darah tinggi, penyakit jantung, diabetes, obesitas, hingga berbagai jenis kanker. Berbagai kondisi masalah kesehatan itu selama ini terbukti meningkatkan risiko fatalitas dampak Covid-19. Di sisi lain, kegiatan olahraga rutin setiap hari berguna pula untuk menjaga kesehatan mental. Olahraga dapat mengurangi risiko depresi, penurunan daya kognitif, demensia, sekaligus bisa menumbuhkan perasaan gembira (Dwyer, Pasini, De Dominicis, \& Righi, 2020).

Pada tugas kesehatan keluarga yang kedua ini juga keluarga diharapkan dapat menjalankan peran untuk memutuskan membawa anggota keluarga jika ada yang sakit unutk berobat ke fasilitas kesehatan, seperti dokter, puskesmas, ataupun rumah sakit. Peran keluarga dalam memutuskan upaya perawatan lanjutan pada anggota keluarga dapat menentukan status kesehatan anggota keluarga di masa depan.

Tugas kesehatan keluarga yang ketiga yakni merawat keluarga yang mengalami gangguan kesehatan. Artinya, keluarga diharapkan mampu merawat dengan benar anggota keluarganya yang sakit agar segera sehat seperti sebelumnya. Jika anggota keluarga ada yang mengalami Covid-19, keluarga harus memiliki peran yang kuat dalam merawat anggota keluarga yang sakit. Fokus perawatan keluarga yang diberikan kepada anggota keluarga yang sakit didasari penerapan family centered care (Hart et al., 2020). Model Family Centered Care memandang keluarga secara holistik, bahwa jika salah satu anggota keluarga mendapatkan masalah, maka akan mempengaruhi anggota keluarga yang lainnya (Friedman et al., 2010). Model ini 
bertujuan untuk meningkatkan kemandirian keluarga dalam upaya pencapaian kesehatan yang maksimal bagi seluruh anggota keluarga (Friedman et al., 2010). Dukungan keluarga dibutuhkan pada masa anggota keluarga sakit. Dukungan keluarga adalah sikap, tindakan dan penerimaan keluarga dengan penderita yang sakit. Keluarga juga berfungsi sebagai sistem pendukung bagi anggotanya dan anggota keluarga memandang bahwa orang yang bersifat mendukung, selalu siap memberikan pertolongan dan bantuan jika diperlukan (Nusi, Wijayanti, \& Rahayu, 2010).

Friedman et al., (2010) mengemukakan ada empat jenis dukungan keluarga, yaitu:

- Dukungan informasional

Yaitu keluarga berfungsi sebagai sebuah kolektor dan diseminator (penyebar informasi). Menjelaskan pemberian saran, sugesti, informasi yang dapat digunakan mengungkapkan suatu masalah. Manfaat dari dukungan ini adalah dapat menekan munculnya suatu stressor karena informasi yang diberikan dapat menyumbangkan aksi sugesti yang khusus pada individu. Aspek-aspek dalam dukungan ini adalah adalah nasehat, usulan, saran, petunjuk dari pemberian informasi.

- Dukungan instrumental

Yaitu keluarga merupakan sumber pertolongan praktis dan konkrit. Dukungan betuk ini bertujuan untuk mempermudah seseorang dalam melakukan aktifitasnya berkaitan dengan persoalan-persoalan yang dihadapinya, atau menolong secara langsung kesulitan yang dihadapi, misalnya: memperhatikan kesehatan, dalam hal makan, minum, istirahat, menyediakan obat-obatan yang dibutuhkan, terhindarnya penderita dari kelelahan.

- Dukungan emosional

Keluarga sebagai sebuah tampat yang man dan damai untuk istirahat dan pemulihan serta membantu penguasaan terhadap emosi. Aspek-aspek dari dukungan emosional yaitu diantaranya dukungan yang diwujudkan dalam bentuk afeksi (kasih sayang), adanya kepercayaan, perhatian, mendengarkan dan didengarkan.

- Dukungan penilaian (apprasial)

Yaitu keluarga bertindaki sebagai sebuah umpan balik, membimbing dan menengahi pemecahan masalah dan sebagai sumber dan validator identitas keluarga, diantaranya memberikan support, pengakuan, penghargaan, dan perhatian.

Dukungan keluarga dapat diperoleh dari dukungan eksternal maupun dukungan internal (Yuniar \& Darmawati, 2017). Dukungan eksternal bisa diperoleh dari sahabat,rekan pekerjaan, tetangga, sekolah, keluarga besar, kelompok sosial, kelompok rekreasi, tempat ibadah, dan praktisi kesehatan.Sedangkan dukungan internal bisa didapatkan dari suami atau istri, dan saudara kandung, atau dukungan 
dari anak. Dukungan keluarga ini mendukung pemenuhan tugas kesehatan keluarga untuk dapat merawat anggota keluarga yang sakit selama masa pandemi Covid-19.

Selanjutnya tugas kesehatan yang keempat adalah memodifikasi lingkungan keluarga untuk menjamin kesehatan keluarga. misalnya, dengan memelihara lingkungan tempat tinggalnya agar tidak menimbulkan penyakit. Modifikasi lingkungan ini sangat dibutuhkan selama pandemi Covid-19. Bentuk modifikasi disesuaikan dengan kemampuan keluarga dalam memfasilitasi seluruh anggota keluarga dalam upaya pencegahan dan penangulangan Covid-19. Beberapa upaya modifikasi yang sebaiknya dilakukan keluarga dalam upaya adaptasi selama masa pandemi ini meliputi modifikasi aktivitas keluarga yang biasanya aktif di luar untuk menjadi berdiam di rumah saja. Orang tua memegang peranan penting untuk tetap melakukan upaya modifikasi pembelajaran pada anak, pekerjaan pada orang tua, serta modifikasi pemenuhan asupan nutrisi gizi seimbang pada keluarga dengan melakukan perubahan jadwal belanja menjadi $1 \mathrm{x}$ seminggu dengan perbedaan kuantitas yang disesuaikan untuk kebutuhan 1 minggu. Modifikasi lainnya terkait fasilitas PHBS di rumah dan lingkungan rumah untuk meminimalkan resiko paparan virus.

Tugas kesehatan keluarga yang terakhir yakni mampu memanfaatkan fasilitas pelayanan kesehatan di sekitarnya bagi keluarga. artinya, keluarga akan membawa anggota keluargnya yang sakit ke fasilitas kesehatan terdekat atau fasilitas kesehatan yang disukai. Peran keluarga untuk melaksanakan hal tersebut seringkali dipengaruhi oleh stigma yang muncul di masyarakat terhadap pasien Covid-19, sehingga seringkali keluarga merasa ragu untuk membawa anggota keluarga nya melakukan test, tracing, serta perawatan di rumah sakit. Tingkat stigma terkait COVID-19 didasarkan pada tiga faktor utama: 1) COVID-19 merupakan penyakit baru dan masih banyak yang belum diketahui; 2) kita sering takut akan hal yang tidak diketahui; dan 3) ketakutan mudah dikaitkan dengan orang lain. Stigma dapat merusak kohesi sosial dan mendorong terjadinya kemungkinan isolasi sosial terhadap kelompok, yang dapat berkontribusi pada situasi yang justru lebih memungkinkan, bukan mencegah, penyebaran virus (WHO, 2020b). Hal ini dapat mengakibatkan masalah kesehatan yang lebih parah dan kesulitan mengendalikan wabah penyakit. Keluarga harus dapat mengambil keputusan terbaik dan jangan terpengaruh oleh stigma yang ada untuk tetap mencari perawatan kesehatan jika ada anggota keluarga yang menderita Covid-19.

Optimalisasi tugas kesehatan keluarga pada setiap keluarga akan mampu meningkatkan derajat kesehatan seluruh anggota keluarga selama masa pandemi Covid-19. Peran Keluarga dalam memberikan dukungan kepada setiap anggota keluarga terutama dalam penerapan protokol kesehatan yang dianjurkan akan dapat menekan laju angka kesakitan akibat Covid-19 terutama pada kluster keluarga. Hal ini akan keluarga indonesia yang sehat, tangguh dan mampu menjalankan seluruh tugas kesehatan keluarga secara optimal. 


\section{Daftar Pustaka}

Borak, J. (2020). Airborne Transmission of COVID-19. Occupational Medicine.

Dwyer, M. J., Pasini, M., De Dominicis, S., \& Righi, E. (2020). Physical activity: Benefits and challenges during the COVID-19 pandemic. Scandinavian Journal of Medicine \& Science in Sports, 30(7), 1291.

Friedman, M. M., Bowden, V. R., \& Jones, E. G. (2010). Family nursing textbook: Research, theory, and practice. Jakarta: EGC.

Hart, J. L., Turnbull, A. E., Oppenheim, I. M., \& Courtright, K. R. (2020). FamilyCentered Care During the COVID-19 Era. Journal of Pain and Symptom Management, 60(2), e93-e97. https://doi.org/10.1016/j.jpainsymman.2020.04.017

Islam, N., Sharp, S. J., Chowell, G., Shabnam, S., Kawachi, I., Lacey, B., ... White, M. (2020). Physical distancing interventions and incidence of coronavirus disease 2019: Natural experiment in 149 countries. The BMJ, 370, 1-10. https://doi.org/10.1136/bmj.m2743

Kalil, A., Mayer, S., \& Shah, R. (2020). Impact of the COVID-19 Crisis on Family Dynamics in Economically Vulnerable Households. SSRN Electronic Journal. https:/ /doi.org/10.2139/ssrn.3706339

Kemenkes RI. (2020). KMK No. HK.01.07-MENKES-413-2020 tentang Pedoman Pencegahan dan Pengendalian COVID-19.

Kementrian Kesehatan Republik Indonesia. (2011). Peraturan Menteri Kesehatan Republik Indonsesia Nomor 2046/MENKES/PER/XII/2011. Jenis Penyakit Menular Tertentu Yang Dapat Menimbulkan Wabah Dan Upaya Penanggulangan, 1-30. https://doi.org/10.1093/nar/gkv1124

Malkawi, S. H., Almhdawi, K., Jaber, A. F., \& Alqatarneh, N. S. (2020). COVID-19 Quarantine-Related Mental Health Symptoms and their Correlates among Mothers: A Cross Sectional Study. Maternal and Child Health Journal, (0123456789). https://doi.org/10.1007/s10995-020-03034-x

Notoatmodjo, S. (2012). Promosi kesehatan dan perilaku kesehatan. Jakarta: Rineka Cipta, 45-62.

Nusi, F., Wijayanti, R., \& Rahayu, E. (2010). Hubungan antara Dukungan Keluarga dengan Respon Sosial pada Lansia di Desa Sokaraja Lor Kecamatan Sokaraja. Jurnal Keperawatan Soedirman, 5(1), 30-36.

Presiden Republik Indonesia. (2013). Peraturan Pemerintah Republik Indonesia Nomor 40 Tahun 1991 tentang Penanggulangan Wabah Penyakit Menular. Pp/Ri/40/1991, 53(9), 1689-1699. https://doi.org/10.1017/CBO9781107415324.004

Spinelli, M., Lionetti, F., Pastore, M., \& Fasolo, M. (2020). Parents' Stress and Children's Psychological Problems in Families Facing the COVID-19 Outbreak in Italy. Frontiers in Psychology, 11. https:// doi.org/10.3389/fpsyg.2020.01713

Stanhope, M., Faan, R. N. D., Lancaster, J., \& Faan, R. N. P. (2019). Public Health Nursing E-Book: Population-Centered Health Care in the Community. Elsevier Health Sciences.

Watamura, S. E., \& Koppels, T. (2020). Stress and parenting during the global COVID-19 pandemic. (January).

WHO. (2020a). Infection prevention and control during health care when COVID-19 is suspected: interim guidance, 19 March 2020.

WHO. (2020b). Stigma Sosial Terkait Dengan COVID-19. Unicef, 1-5.

WHO. (2021). WHO Coronavirus Disease (COVID-19) Dashboard. Retrieved from https:/ / covid19.who.int/?gclid=Cj0KCQiAst2BBhDJARIsAGo2ldW4- 
pEO9AoMwJBusY8yQdFsmQ1srz2FxxlVeRpyWkJw-

88QKEWBU3AaAiopEALw_wcB

Yuniar, D., \& Darmawati, I. (2017). Dukungan Keluarga Berhubungan Dengan

Kecerdasan Emosional Remaja. Jurnal Keperawatan Komprehensif (Comprehensive Nursing Journal), 3(1), 9-17.

\section{Biografi Singkat}

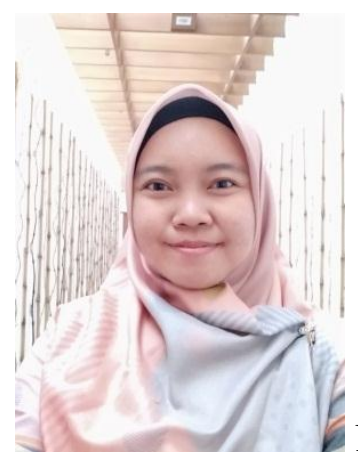

Penulis bernama lengkap Irma Darmawati.,M.Kep.,Ns.Sp.Kep Kom. Tempat lahir Bandung, 9 Mei 1987, Anak pertama dari tiga bersaudara. Alumnus Program Spesialis Keperawatan Komunitas Universitas Indonesia. Sekarang mengabdi sebagai dosen di Universitas Pendidikan Indonesia.

Penulis mendalami kekhususan Keperawatan Komunitas sebagai cabang ilmu keperawatan pada tatanan kesehatan di masyarakat. Penulis memfokuskan penelitian serta karya ilmiah nya pada upaya promotif dan preventif optimalisasi kesehatan keluarga dan masyarakat khususnya agregat anak usia sekolah, remaja, dewasa serta lansia. 